\title{
Optimization of In-planta Method of Genetic Transformation in Pigeon Pea (Cajanus cajan L. Millsp.)
}

\author{
Rouf Ahmad Parray", Rahul Kaldate and Rahul Chavan
}

Vilasrao Deshmukh College of Agricultural Biotechnology, Latur, Vasantrao Naik Marathwada Krishi Vidyapeeth, Parbhani-431402, Maharashtra, India

*Corresponding author

\section{Keywords \\ Agrobacterium, GUS gene, In- planta, Genetic transformation, Pigeon pea \\ Article Info \\ Accepted: 04 May 2019 Available Online: 10 June 2019}

\begin{abstract}
A B S T R A C T
Pigeon pea (Cajanus cajan L. Millsp.) is one of the major grain legume crops of the tropics and sub-tropics grown in about 50 countries of Asia, Eastern and Southern Africa and the Caribbean for various uses such as food, fodder and firewood. The present study was conducted to develop and optimize tissue culture independent in planta transformation system in pigeonpea. This system can help in widening genetic base as well as solutions over various biotic and abiotic factors through engineering novel genes across the species. The various transformation parameters viz., Optical density of Agrobacterium suspension, virulence inducer and infection time were optimizad through 18 different treatment combinations. The plumular and inter cotyledonary meristem axes of 2-3 days old germlings of pigeon pea cv. BSMR 853 was exploited for Agroinfection by sewing needles. Out of 270 inoculated germlings 11.34 mean number of plantlets were recovered. The putative transformants were confirmed by GUS histochemical and PCR assay. Among 18 different treatment combinations, the treatment pertaining Agrobacterium suspension of O.D 1.0, virulence inducer (acetosyringone) at $250 \mu \mathrm{M} / \mathrm{ml}$ and infection time of $1.0 \mathrm{~min}$ was found optimum has shown significant impact on transformation efficiency. The treatment comprising bacterial O.D, 1.0 with $250 \mu \mathrm{M} / \mathrm{ml}$ acetosyringone and 1.0 infection time 1.0 min revealed $90.02 \%$ transformation efficiency. However, lowest transformation frequency i.e. $68.76 \%$ was reported in treatment of bacterial O.D. 1.5 with $150 \mu \mathrm{M} / \mathrm{ml}$ acetosyringone and $0.5 \mathrm{~min}$. infection time. The present investigation revealed the optimization of in planta transformation parameters in pigeon pea and suitability of genotype BSMR853 for genetic transformation and further genetic improvement.
\end{abstract}

\section{Introduction}

Pigeon pea (Cajanus cajan L.) is an important grain legume of the semi-arid tropics and form a significant component of the diet of vegetarians. Pigeon pea is member of family fabaceae, order fabales and genus Cajanus. It is often cross-pollinated crop (20-70 per cent) having diploid chromosome number $(2 \mathrm{n}=22)$ with an estimated genome size of $833.07 \mathrm{Mb}$ (Varshney et al., 2011). It is short lived perennial, but traditionally, it is cultivated as an annual crop in Asia, Africa, Caribbean region and Latin America. Thus, it is 
becoming one of the major grain legume crops of tropics and subtropics. Considering natural genetic variability in pigeon pea and presence of its wild relatives in the region, it has been postulated that, India is the primary center of origin of pigeon pea (Saxena et al., 2008). Globally, it is cultivated on 4.92 mha with annual production of $3.65 \mathrm{mt}$ and productivity is of $898 \mathrm{~kg} / \mathrm{ha}$. About $90 \%$ of the global pigeon pea area falls in India corresponding to $93 \%$ of global production/ (http://www.icrisat.org). Pigeon pea is second most important leguminous crop grown in India followed by chickpea. The area, Production and yield of pigeon pea during year 2012-13 in India is $3.38 \mathrm{mha}, 2.27 \mathrm{mt}$ and $671 \mathrm{~kg} / \mathrm{ha}$ respectively (Kaur et al., 2012). Pigeon pea seeds contain about 20$22 \%$ protein and appreciable amounts of essential amino acids viz., Methionine and Cysteine and minerals (Saxena et al., 2008). It is a favorite crop of small holder dryland farmers, as it can grow well under subsistence level of agriculture and provides nutritive food, fodder and fuel wood. It is also a good source of fibers, vitamins and minerals. Pigeon pea is an excellent source of vitamin $\mathrm{D}$ and it also improves soil by fixing atmospheric nitrogen.

The production of pigeon pea is constrained by use of unfertile land, water logging or dry spells during critical stages of crop growth, pest and diseases problems, narrow genetic base and lack of drought-resistant, nonavailability of high-yielding genotypes. The conventional plant breeding approach with improved agricultural practices is not found enough to improve the pigeon pea production over last 50 years. While the application of various advancements in molecular biology, genetic transformation and in-vitro techniques have significantly contributed to improve the production and quality of several crops. However, these modern tools have not been commercialised in pigeon pea to combat the severe losses caused by several biotic (i.e. pest and diseases like Pod borers, Root knot nematodes, Fusarium wilt, Sterility Mosaic etc.) and abiotic (i.e. drought, salinity, water logging etc.) stresses. The chief factor among them is pod borer (Helicoverpa armigera), becoming most serious and being infectious to all cultivated species of pigeon pea. Its larvae attack the flowers and pods of the pigeon pea, resulting in substantial damage and yield losses of over $\$ 300$ million annually worldwide (Shanower et al., 1999). Pod borer problems is complex and intractable, no single control strategy is successful in keeping its population below economic threshold level (ETL). On the other side, indiscriminate use of pesticides to control pests has led to series of consequences like insect resistance, pest resurgence, outbreak of secondary pest, harmful residual effects, imbalances in natural ecosystem and higher production costs which have been a concern in India and elsewhere. The wild relatives are available in pigeon pea but possess very narrow genetic base towards their improvement of this crop through conventional plant breeding techniques. Therefore, it is becoming important to develop a rapid transformation system for improvement of pigeon pea.

The development in biotechnology facilitates the transfer of cloned and well-defined genes across the plant species through methods of genetic transformation viz., microprojectile bombardment, Agrobacterium-mediated gene transfer, viral vectors, electroporation, sonication, etc. Among these, the most commonly used method for genetic transformation in re-calcitrant crop like pigeon pea is the Agrobacterium mediated gene transformation (Horsch et al., 1985) although it is time consuming, regeneration system dependant and has difficulty while controlling the overgrowth of Agrobacterium etc. Therefore, it is becoming vital to develop 
and optimize In-planta transformation system in pigeon pea which enables rapid gene transformation in pigeon pea. A key component of most of the functional genomics approaches is a high-throughput transformation system which is emerging as an important tool of crop improvement. Transformation technique also offers strategies for over expression or suppression of endogenous genes to generate new phenotypic variation towards investigation of gene function for crop improvement. Thus, it is imperative to have an efficient regeneration and transformation system in order to introduce novel traits in crop like pigeon pea. Therefore, in view of development of tissue culture independent rapid transformation system towards improvement of pigeon pea, optimization of In-planta transformation system was attempted to optimize In-planta transformation conditions and molecular analysis of pigeon pea transformants.

\section{Materials and Methods}

\section{Plant material}

Seeds of pigeon pea cultivar BSMR 853 procured from Agricultural Research Station (ARS), Badnapur were used during course of this investigation. The seeds were washed in distilled water initially and then rinsed in $70 \%$ ethanol for 5 minutes. This step was repeated twice. Then the seeds were treated with $0.1 \%$ $\mathrm{HgCl}_{2}$ solution followed by washing in double distilled water for 5 minutes to remove the traces of surface sterilent. The sterilized seeds were placed in $1 / 2 \mathrm{MS}$ seed germination medium for 3-5 days.

\section{Procedure for in planta transformation of pigeon pea}

Agrobacterium tumefaciens strain, EHA101 harbouring the binary plasmid $p B I 121$ containing GUS gene procured from NRCPB,
New Delhi was used for transformation. The vector contains the neomycin phosphotransferase II (nptII) gene driven by the nopaline synthase promoter. Agrobacterium was grown overnight at $28^{\circ} \mathrm{C}$ in $25 \mathrm{ml}$ of YEM medium (pH 7.0) containing $50 \mu \mathrm{g} / \mathrm{ml}$ kanamycin. The bacterial culture was later pelleted at $6000 \mathrm{rpm}$ for $5 \mathrm{~min}$. The Agrobacterium pellets were resuspended in $50 \mathrm{ml}$ liquid $1 / 2 \mathrm{MS}$ medium and stored at $4^{\circ} \mathrm{C}$ till further use. The suspension culture approximately $15 \mathrm{ml}$ of Agrobacterium strain EHA101 harboring GUS gene was taken separately in sterile petri-plate. Further acetosyringone was added at different concentrations $(150,200$ and $250 \mu \mathrm{M})$ to increase efficiency of transformation. The needle incised germinated seedlings were dipped into the suspension culture containing GUS gene in $1 / 2$ MS media for 5-10 seconds and shake at $50 \mathrm{rpm}$ for 5 minutes. The seedlings were removed from the suspension culture and dried on sterile filter paper. Further the inoculated seedlings/ germlings were sown in plastic cup containing sterile cocopeat. Further these plants were transferred into plastic pot containing sand, soil and FYM and grown upto maturity in green house.

\section{Histochemical $G U S$ analysis}

The histochemical GUS assay was performed at shoot initiation and developmental stage of transformed pigeon pea plants. This assay was used to check the presence of GUS gene incorporation into transformed pigeon pea plants. Shoots of putative pigeon pea transformants were dipped into $20 \mathrm{ml}$ assay solution and incubated at $37^{\circ} \mathrm{C}$ overnight in the dark chamber wrapped in aluminium foil. Based on appearance of blue colour precipitate in pigeon cells qualitative analysis of pigeon pea transformation was performed. The histochemical GUS analysis to determine the $\beta$-glucuronidase activity in the putatively 
transformed plantlets was carried out in accordance with Jefferson et al., (1987).

\section{Molecular analyses of the putative transgenic plants}

Tissues from the progeny plants were analyzed for the presence of the introduced gene. Genomic DNA was isolated following the procedure of Lie et al., (2007) from fresh leaf tissue from greenhouse-grown $T_{0}$ generation and that was used for polymerase chain reaction (PCR). PCR was performed to amplify a 750 bp nptII gene fragment. PCR was initiated by an initial denaturation at 94 ${ }^{\circ} \mathrm{C}$ for $4 \mathrm{~min}$ followed by 30 cycles of $1 \mathrm{~min}$ at $94{ }^{\circ} \mathrm{C}, 1 \mathrm{~min}$ at $56{ }^{\circ} \mathrm{C}$ and $1.5 \mathrm{~min}$ at $72{ }^{\circ} \mathrm{C}$. The amplified PCR product was separated on $1.2 \%$ agarose gel, stained with ethidium bromide dye and visualized under gel documentation System. Similarly, the PCR was also performed with DNA of nontransformed pigeon pea plant as a negative control. Based on number of plants recovered and GUS positive plant derived after PCR confirmation, transformation efficiency was calculated.

\section{Results and Discussion}

\section{Seedling development and infection}

Five days old seedlings (Figure 1a, 1b) grown on $1 / 2$ MS medium were isolated aseptically under Laminar Air Flow cabinet. Each of Agrobacterium suspension of different treatment combinations, acetosyringone was taken into separate sterile petri-dish. Wherein, eighteen different treatment combinations were adopted towards optimization of three important transformation parameters viz., O.D. of Agrobacterium, concentrations of virulence inducer, inoculation time etc. during in planta pigeon pea transformation. Fifteen plants were infected under each treatment. Seedlings with plumule just emerging were pierced at the apical meristem of axis and at the intercotyledonary region with a sterile needle and infected by immersion in the suspension of Agrobacterium for 0.5 to1.5 min. After infection, seedlings were washed briefly with sterile water and planted in plastic cup containing sterilized cocopit (Figure 2). The planted seedlings were maintained at control conditions in greenhouse. During this experiment the explant comprising axis of apical meristem and intercotyledonary region gave better response for Agrobacterium co-cultivation and further recovery of seedlings post cocultivation. Similar procedure of agroinfection was adopted by Rao et al., (2008) for Agroinfection of pigeon pea. In addition, Keshamma et al., (2008) observed that, embryonic axes showed better response towards agro-infection and recovery of seedlings compared to other explants. While, in tomato embryonic apical meristem was found efficient during in planta transformation experiment (Supratna et al., 2006).

\section{Green house maintenance of transformed plants}

Initially, a total of 270 plants of 18 different treatment combinations were grown in plastic cup containing sterilized coco-pit at green house conditions (Figure 3a). These plants were covered with polythene bags for 2-3 days to maintain high humidity. Further fully established seedlings were transferred into plastic pots containing sand, soil and FYM (2:1:1) at containment type green house (Figure 3b). These plants were allowed to grow upto the maturity stage and further covered with muslin cloth in order to harvest seed for next progeny (Figure 4). The survival rate of the plant at green house condition was calculated. On an average the maximum recovery of plantlets was observed upto $75.60 \%$ (Table 1b). It was revealed that, the 
germination process of pigeon pea after in planta transformation remains unaffected. Similar type of results was recorded by Rao et al., (2008) and described that, germination percentage and growth process of germinating embryos do not have any adverse effect of Agrobacterium during transformation. They reported fresh and healthy seedlings with germination frequency of $50 \%$ during prolonged time i.e. $1 \mathrm{~h}$ infection period.

\section{Optimization of in planta method of pigeon pea transformation}

The in-planta transformation parameters comprising, bacterial O.D (0.5, 1.0 and 1.5 min.), virulence inducer i.e. acetosyringone (150, 200 and $250 \mu \mathrm{M} / \mathrm{ml})$ and inoculation period $(0.5,1.0$ and $1.5 \mathrm{~min})$ were assessed through 18 different treatment combination (Table 1a). The putative pigeon pea transformants grown at green house conditions were further assessed for confirmation of transgene integration. Further, the best treatment conditions were evaluated by adjudging optimal concentration of transforming parameters in genotype BSMR 853.

\section{Confirmation of transformed plants by histochemical GUS assay}

Leaf samples of greenhouse grown transformed pigeon pea plants were collected at different developmental stages viz., seedling, branching and maturity stage and further tested for histochemical GUS analysis. The histochemical GUS assay discriminated the transformed and non-transformed pigeon pea plantlets of cv. BSMR 853. The transformed plantlets showed blue color precipitate at midrib area of leaf, stem and on younger leaves (Figure 5a, 5c). The plantlet developed through each treatment was screened through histochemical GUS assay. However, the histochemical GUS assay was also adopted with non- transformed /control plantlets of the same cv. BSMR853 wherein, they did not show the blue color precipitates on tested leaf sample (Figure 5b). The histochemical GUS assay method described by Jefferson et al., (1987) is simple, rapid and require less expertise. Many of researchers used this method for confirmation of transgene as Rao and Rohini (1999) utilized this method for confirmation of pigeon pea transformants, Keshamma et al., (2008) in cotton; Ombori et al., (2013) in maize; Ching et al., (1997) and Razzaq et al., (2011) in wheat; Lee et al., (2011) in soybean crop plants. They revealed that, GUS gene expressed plants grew normally and remain fertile. Similarly, GUS is very stable and tissue extracts continue to show high levels of GUS activity after prolonged stage of harvested samples (Jafferson et al., 1987). It could help to make simplicity in histochemical analysis via. collecting and preserving samples for longer duration. Thus, during this course of investigation an attempt have been made to optimize in planta transformation protocol in pigeon pea by using GUS reporter gene.

\section{Confirmation of transformed plant by PCR analysis}

The genomic DNA extracted from putative pigeon pea transformants of genotype BSMR 853 was subjected to PCR amplification with GUS gene specific primer. The PCR amplified product was resolved on $1.2 \%$ agarose gel. The 9.25 mean number of putative transformants showing $750 \mathrm{bp}$ amplicon (Figure 6) was considered as $G U S$ gene positive pigeonpea plants. While those lacking were designated as non-transformed plants. Based on histochemical GUS assay and PCR confirmation the transformation efficiency of genotype BSMR 853 was calculated. The GUS histochemical based early detection of transformants was not 
recommended in pigeon pea, as it gave false positive due to endogenous $G U S$ like activity exhibited by pigeon pea (Rao et al., 2008) and other crops (Sudan et al., 2006). Hence in present investigation, PCR based confirmation of transformants was adopted. Similarly, this kind of approach was adopted by many of the researchers in different crops namely, Lin et al., (2009) in rice; Supartana et al., (2006) and Razzaq et al., (2011) in wheat; Lee et al., (2011) in soybean etc.

\section{Optimization of transformation parameters}

Efficient transformation systems using readily available explants are in high demand for agronomically important plants. Though fertile transgenic plants have been generated from a greater number of plants, yet the transformation frequency for most species is still low. Agrobacterium-mediated transformation technology has not been routinely applied to pigeon pea because of recalcitrant approach (Rao et al., 2008). However, the in vitro regeneration systems available in pigeon pea limited to few genotypes and morphogenetic response of the pigeon pea is known to be a genotype specific phenomenon described by Mohan \& Krishnamurty (1998). Hence, further optimization of the transformation parameters such as bacterial OD, inoculation time and virulence inducer would be useful to increase in planta transformation efficiency.

During this investigation, the average transformation efficiency was calculated based on mean number of survived plantlets and actual transformed plantlets under each treatment of transformation experiment. The Agrobacterium OD, 1.0 was found more effective for transient expression of GUS gene (Table 1b). The maximum numbers of transformed plants were obtained at OD 1.0 under each treatment compare to OD 0.6 and
1.5. The transformation efficiency of genotype, BSMR 853 was ranged between 68.76 to $90.02 \%$. It was also observed that, increase in concentration of O.D i.e. of 1.5 as well as decrease in concentration of O.D. i.e. of 0.6 laid impact on decrease in transformation efficiency of genotype BSMR 853. Moreover, higher density of $A$. tumefaciens could increase the transient GUS expression but could not give stable transformation frequency. Similar findings were also reported by Cheng et al., (1997) \& Supatana et al., (2006).

The second transformation parameter, i.e. inoculation time of $1.0 \mathrm{~min}, 3 \mathrm{~min}$ and $5 \mathrm{~min}$ were assessed through different treatment combinations with other parameters. The effect of inoculation time was not much correlated with percent transformation efficiency. It was highest at lower inoculation time $(0.3 \mathrm{~min})$. However, it was also found highest at higher inoculation time (1.5 min). The influence of lower as well as higher inoculation time was found at par with each other. The range of $G U S$ expression and transformation efficiency among transformed pigeon pea plants were ranged between 68.76 to $90.02 \%$. Further, it was noticed that, the hardened seedlings of pigeon pea remained fresh and healthy after infection with Agrobacterium. Thus, it was concluded that, there is no more effect of Agroinfection to the germination of seedlings in pigeon pea. Maximum number of plantlets gets recovered after infected with Agrobacterium. Thus, inoculation time had not much influence interms of GUS expression, seedlings germination and transformation efficiency.

Similar type of observations was reported by Rao et al., (2008), wherein they revealed that, seedlings of pigeon pea cv. TTB7 remained unaffected after prolonged inoculation time. They also stated that, there was no effect of agroinfection on germination frequency and 
infected seedlings. It remained fresh and healthy even the infection time is prolonged to $1 \mathrm{~h}$. In addition, the study in rice by Wagiran et al., (2010) reported that, inoculation time did not have any effect on GUS expression and transformation efficiency. They added, the inoculation time was different in different plant species and type of explant dependent, and it might be due to susceptibility of explant to Agrobacterium infection.

The addition of virulence inducer i.e. acetosyringone during transformation experiment showed significant influence on transient expression of GUS gene. Inclusion of $250 \mu \mathrm{M} / \mathrm{ml}$ acetosyringone in Agrobacterium suspension during infection results in the highest $G U S$ activity i.e. $90.02 \%$ for pigeon pea genotype, BSMR 853. While, the acetosyringone at concentration 150 $\mu \mathrm{M} / \mathrm{ml}$ showed minimum transformation efficiency i.e. of $68.76 \%$ of the genotype. This result is supported with evidence reported earlier by Wagiran et al., (2010) in rice cultivars wherein, they stated as increase in concentration of acetosyringone beyond $300 \mu \mathrm{M}$ resulted into decline of percentage of GUS activity. In present study, virulence inducer i.e. acetosyringone played a crucial role towards enhancing the transformation of pigeon pea. The addition of acetosyringone in co-cultivation media activates the induction of vir genes and extends the host range of Agrobacterium strains (Saharan et al., 2004; Zhao et al., 1998). They have also stated that, the optimum concentration of acetosyringone in view of induction of highest transformation efficiency was varied from genotype to genotype. Thus, in present investigation the treatment combination comprising bacterial O.D 1.0, $250 \mu \mathrm{m} / \mathrm{ml}$ acetosyringone and inoculation time $1.0 \mathrm{~min}$ was found optimum for transformation of genotype BSMR 853 (Table 1b).

Earlier, similar type of experiments on optimization of transformation parameters in different crops have been attempted by several researchers viz., in pigeon pea (Rao et al., 2008); cotton (Keshamma et al., 2008); buckwheat (Kojima et al., 2000); mulberry (Ping et al., 2003); soybean (Chee et al., 1989); rice (Supartana et al., 2005) etc. The present investigation could result in the standardization of an efficient in planta transformation protocol in pigeon pea which gave $68.76-90.02 \%$ transformation efficiency in genotype BSMR 853 (Table 1b). This protocol optimized in this study is found efficient and does not involve any tissue culture regeneration procedure. Also, the protocol could generate relatively large number of $\mathrm{T}_{0}$ transgenic in a short time. Similar findings were also reported earlier by Rao et al., (2008) in pigeon pea and Rohini et al., (1999) by producing 50-76.60\% transformation efficiency in sunflower genotype Morden while Lucas et al., (2000) reported 45-62\% transformation efficiency in sunflower $c v$. LSF 8.

Table.1a Optimized transformation parameters viz., bacterial OD, virulence inducer and inoculation period

\begin{tabular}{|l|c|c|}
\hline \multicolumn{1}{|c|}{ Transformation parameters } & Value of parameter taken & Optimized value of parameters \\
\hline Bacterial density (OD600) & $0.5,1.0,1.5$ & 0.5 \\
\hline $\begin{array}{l}\text { Virulence inducer, } \\
\text { Acetosyringone }(\boldsymbol{\mu M} / \mathbf{m l})\end{array}$ & $150,200,250$ & 250 \\
\hline $\begin{array}{l}\text { Inoculation period of } \\
\text { Agrobacterium (min) }\end{array}$ & $0.5,1.0,1.5$. & 1.0 \\
\hline
\end{tabular}


Table.1b Transformation efficiency of pigeonpea genotype BSMR 853

\begin{tabular}{|c|c|c|c|}
\hline Treatment combination & \multicolumn{3}{|c|}{ Pigeon pea cv. BSMR 853} \\
\hline $\begin{array}{c}\text { OD600 + Virulence } \\
\text { inducer }(\mu \mathrm{M})+ \\
\text { Inoculation }(\mathrm{min})\end{array}$ & $\begin{array}{l}\text { Mean No. of plants } \\
\text { recovered }\end{array}$ & $\begin{array}{l}\text { Mean No. of plants } \\
\text { transformed }\end{array}$ & Transformation efficiency $(\%)$ \\
\hline $0.6+150+0.5$ & 12.33 & 9.33 & 75.66 \\
\hline $0.6+150+1.0$ & 12.00 & 9.00 & 75.00 \\
\hline $0.6+200+1.5$ & 11.30 & 8.66 & 70.40 \\
\hline $0.6+200+0.5$ & 12.66 & 10.00 & 78.98 \\
\hline $0.6+250+1.0$ & 12.00 & 10.00 & 83.33 \\
\hline $0.6+250+1.5$ & 11.66 & 9.66 & 82.84 \\
\hline $1.0+150+0.5$ & 10.33 & 9.00 & 87.12 \\
\hline $1.0+150+1.0$ & 10.33 & 9.00 & 87.12 \\
\hline $1.0+200+1.5$ & 9.00 & 7.00 & 77.77 \\
\hline $1.0+200+0.5$ & 13.00 & 11.33 & 87.15 \\
\hline $1.0+250+1.0$ & 13.33 & 12.00 & 90.02 \\
\hline $1.0+250+1.5$ & 12.66 & 11.33 & 89.49 \\
\hline $1.5+150+0.5$ & 10.66 & 7.33 & 68.76 \\
\hline $1.5+150+1.0$ & 10.33 & 7.66 & 74.15 \\
\hline $1.5+200+1.5$ & 10.66 & 9.00 & 84.42 \\
\hline $1.5+200+0.5$ & 10.00 & 8.33 & 83.30 \\
\hline $1.5+250+1.0$ & 11.33 & 9.33 & 82.34 \\
\hline $1.5+250+1.5$ & 10.66 & 8.66 & 81.23 \\
\hline Total Mean & 11.34 & 9.25 & 81.06 \\
\hline SD & 1.15 & 1.34 & 6.33 \\
\hline CV & 10.15 & 14.49 & 7.8 \\
\hline SE & 0.27 & 0.31 & 1.49 \\
\hline
\end{tabular}

Transformation efficiency was calculated based on mean number of regenerated plantlets and mean number of transformed plantlets. Each treatment was performed in triplicates with 15 number of seedlings treatment

Fig.1a-1b a, Five days old seedlings of pigeon pea cv. BSMR 853 germinated on 1/2 MS medium; $\mathrm{b}$, washed seedlings used for agroinfection
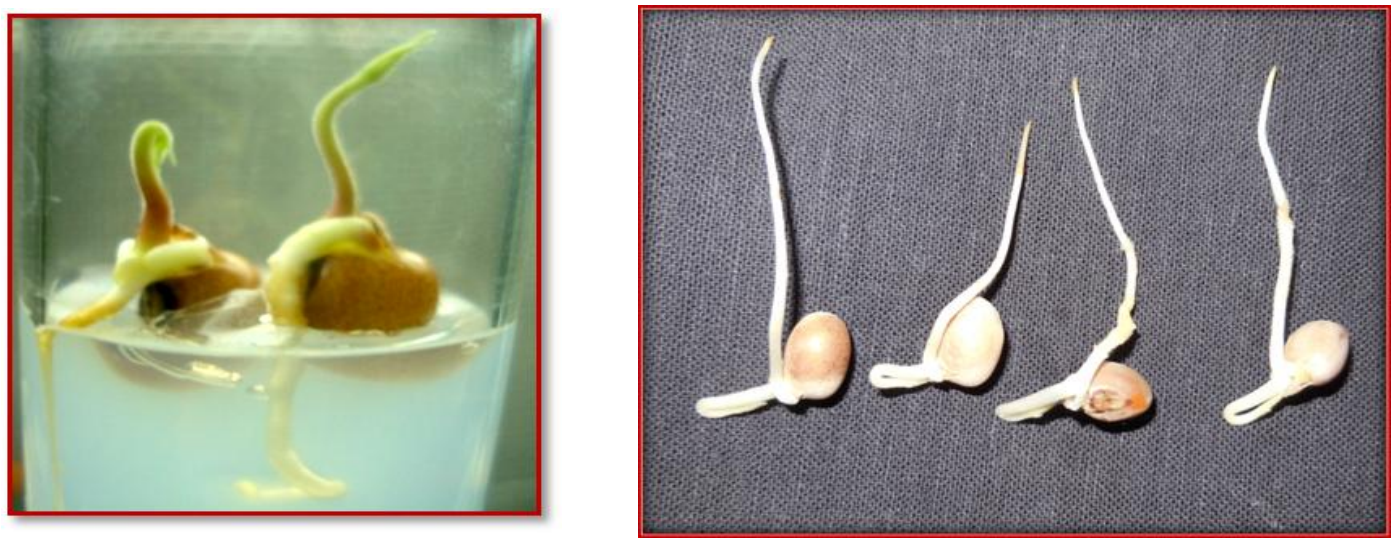
Fig.2 Recovery of agroinfected seedlings of each treatment grown in plastic cup

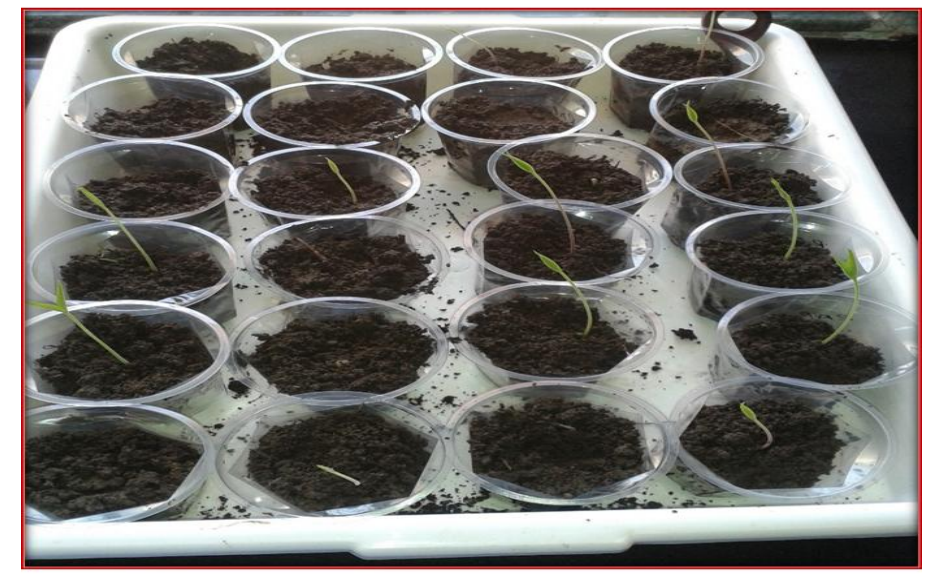

Fig.3a-3b a, putatively transformed seedlings of pigeon pea grown in plastic cup containing coco peat; $b$ putatively transformed seedlings of pigeon pea grown in plastic pot containing Sand, Soil and FYM under greenhouse conditions
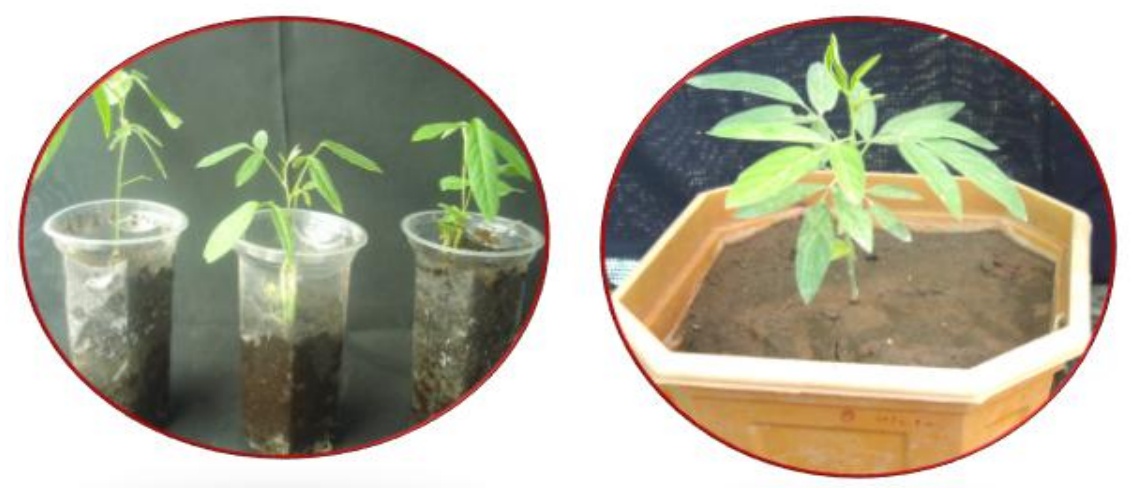

Fig.4 Transformed pigeon pea plantlets were maintained under greenhouse conditions for further selfing and generation of T1 progeny

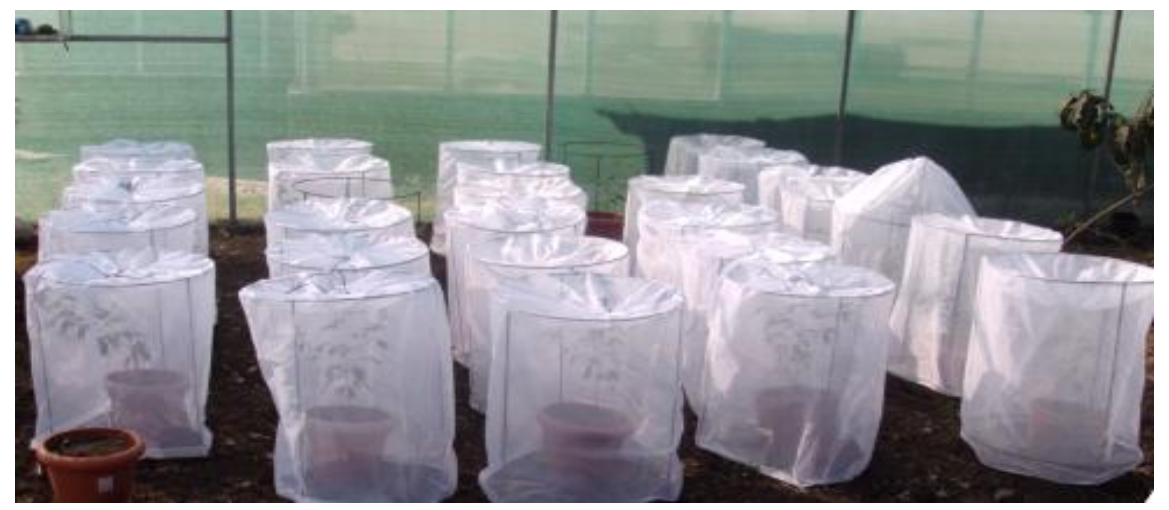


Fig.5a Transformed pigeon pea plantlets showing histochemical GUS gene expression

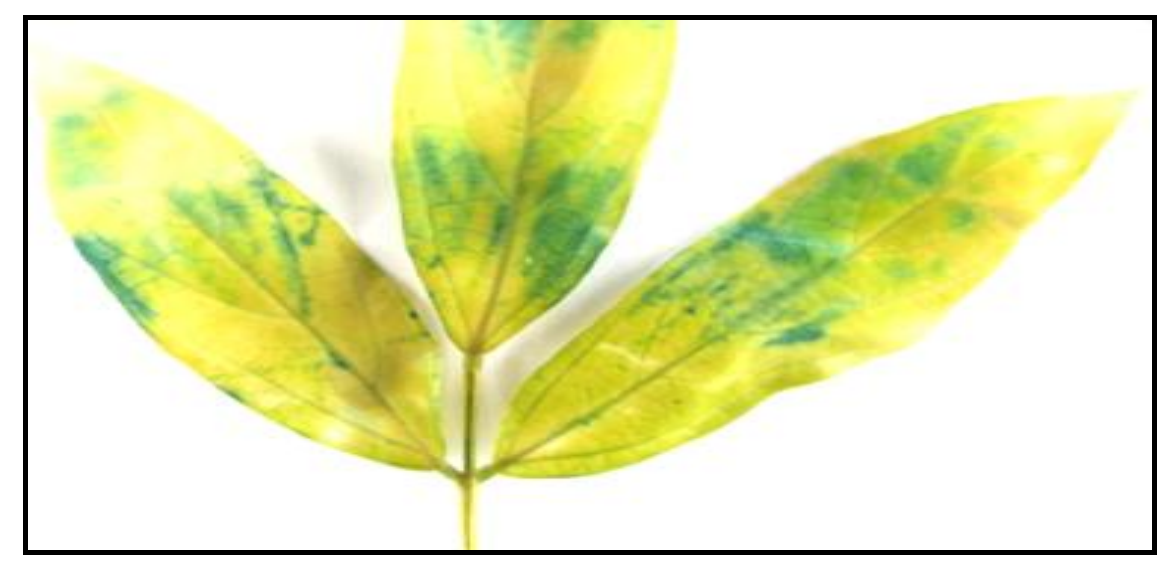

Fig.5b-5c b, Histochemical GUS assay of control plant; c, Histochemical GUS assay of transformed plant
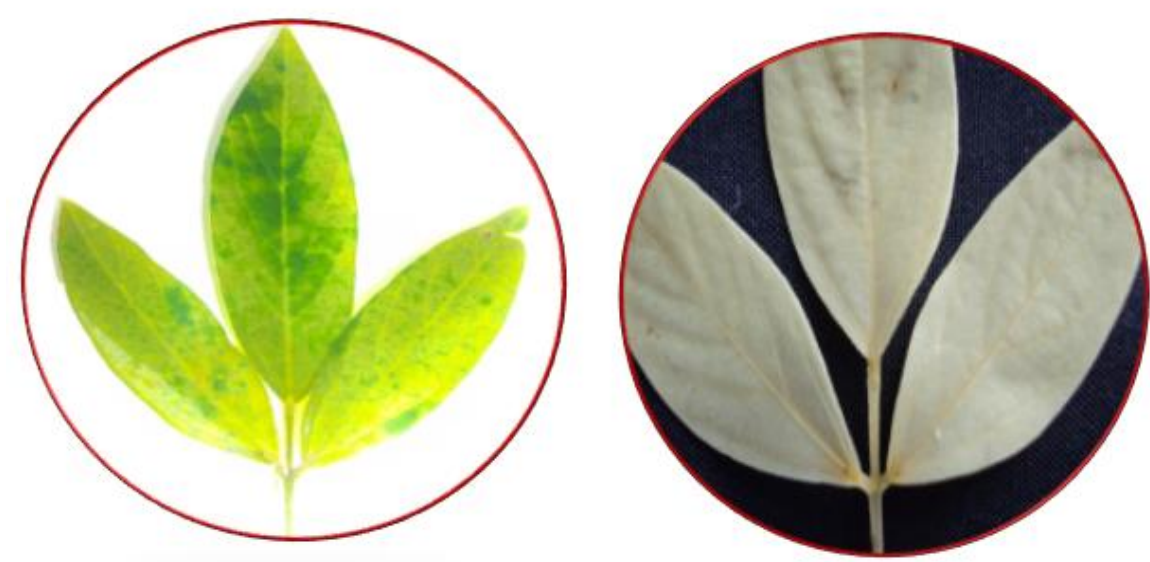

Fig.6 PCR based confirmation of transformed plantlets of pigeon pea by amplifying $750 \mathrm{bp}$ GUS gene amplicon; L, 100 bp DNA ladder; C, Control plant; 1-14, putatively transformed plantlets under screening

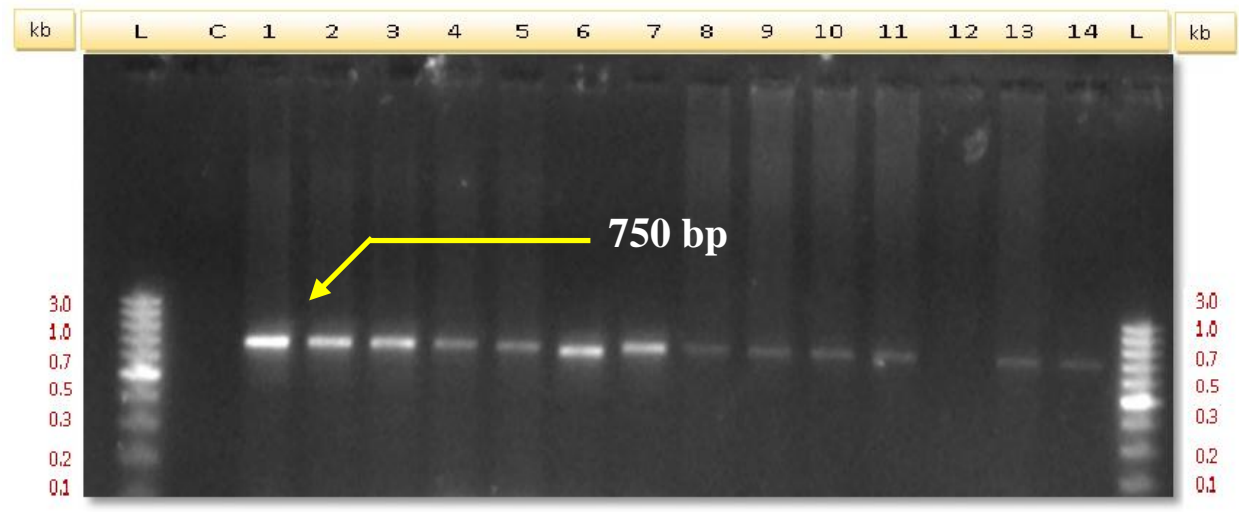


Preliminary experiments suggested that, germination and growth processes of the germinating embryos of pigeon pea remained unaffected in the transformation procedure adopted here. Further steps of hardening of transformed seedling also did not adversely affect the development of the seedlings. The seedlings remained fresh and healthy and the germination frequency was not affected after inoculation of Agrobacterium.

In conclusion, the present investigation revealed the suitability of pigeon pea genotype BSMR853 for future transformation and integration of variety of transgenes towards insect pest, disease resistance and quality improvement etc. through tissue culture independent method developed in this study.

During this study, suitability of growing embryonic axis of cv. BSMR853 towards transformation efficiency was also assessed.

The explant growing embryonic axis provided 11.34 mean numbers of recovered plantlets after co-cultivation. The transformation efficiency based on GUS and PCR assay was found as high as $90.02 \%$ by using embryo as explants for direct Agroinfection. Thus, this investigation concluded with, optimization of tissue culture independent in planta transformation systems in pigeon pea genotype BSMR 853. This protocol would be exploited in genetically as well as qualitatively improvement of pigeon pea through rapid development of transgenic.

\section{Acknowledgement}

Financial and laboratory support from Vilasrao Deshmukh College of Agricultural Biotechnology, VNMKV Parbhani, and ICAR for this research work is gratefully acknowledged.

\section{References}

Chee, P.P., Fober, K. A., Slightom, J. L. (1989). Transformation of soybean (Glycine max) by infecting germinating seeds with Agrobacterium tumefaciens. Plant Physiol. 91, 12121218

Ching, Y.H., and Wang, L. (1999). In-planta Soybean transformation technologies developed in China: Procedure, Confirmation and Field Performance. In-Vitro Cell Dev. Biol Plant. 35: 417420.

Horsch, R.B., Fry, J. E., Hoffman, N. L., Eichholtz, D., Rogers, S. G. and Fraley R.T. (1985). A simple and general method for transferring genes into plants. Science. 227, 1229-1231.

Jefferson, R. A., Kavanagh T. A. and Beven M. W. (1987). GUS fusion: $\beta$ glucuronidase as a sensitive and versatile gene fusion marker in higher plants, EMBO J. 6 (13): 3901-3907.

Kaur, R.A., Devi, R. and Dev, A. (2012). Efficient in vitro regeneration in pigeonpea from cotyledobary node explants. Journal of Cell and Tissue Research, 12(1): 3075-3080.

Keshamma, E., Rohini, S., Rao, K. S., Madhusudhan, B., Kumar, M. (2008). Tissue culture-independent In-planta transformation strategy: an Agrobacterium tumefaciens mediated gene transfer method to overcome recalcitrance in cotton (Gossypium hirsutum L.). J Cotton Sci. 12, 264272.

Kojima, M., Suparthana, P., Jaime, A., Teixeira da Silva., Nogawa, M. (2006) Development of in Planta transformation methods using agrobacterium tumifaciens In: Floriculture, Ornamental and Plant Biotechnology (Vol. IIc 2006). Global Science Books, UK. 
Lee, K., Yi, B. Y., Kim, K. H., Kim, J. B., Suh, S. C., Woo, H. S., Shin, K. S. and Kweon, S. J. (2011). Development of efficient transformation protocol for Soybean (Glycine max L.) and characterization of transgenic expression after Agrobacteriummediated gene transfer. J. Koran Soc. Appl. Biol. Chem. 54(1): 37-45.

Lie, J.T., Yang, J., Chen, D. C., Zhang, X. L., Tang, Z. S. (2007). An optimized minipreparation method to obtain high quality genomic DNA from mature leaves of sunflower. Jr. Genet. Mol. Res., 6(4): 1064-1071.

Lin, J., Zhou, B., Yang, Y., Mei, J., Zhao, X., Guo, X., Huang, X., Tang, D., Liu. X. (2009). Piercing and vacuum infiltration of the mature embryo: a simplified method for Agrobateriummediated transformation of indica rice, Plant Cell Rep., 28: 1065-1074.

Lucas, O., Kallerhoff, J., Alibert, G. (2000). Production of stable transgenic sunflowers (Helianthus annuus L.) from wounded immature embryos by particle bombardment and cocultivation with Agrobacterium tumefaciens. Mol Breed 6, 479-487.

Mohan, M.L. and Krishnamurthy, K.V. (1998). Plant regeneration in pigeon pea (Cajanus cajan (L.) Millsp.) by organogenesis. Plant Cell Rep. 17, 705-710.

Ombori, O., Gitonga, N.M., and Machuka, S. (2008). Somatic embryogenesis and plant regeneration from immature embryos of tropical maize (Zea mays L.) inbred lines. Biotechnology. 7(2): 224-232.

Ping, L.X., Nogawa, M., Nozue, M., Makita, M., Takeda, M., Bao, L. and Kojima, M. (2003). In-planta transformation of mulberry trees (Morus alba L.) by Agrobacterium tumefaciens. J. Insect Biotechnol, Sericol., 72: 117-184.
Rao, K.S., Sreevathsa, R., Sharma, P. D., Keshamma, E., Kumar, M. (2008). Inplanta transformation of pigeonpea: a method to overcome recalcitrancy of the crop to regeneration in vitro, Physiol. Mol. Biol. Plants, 14(4): 321328.

Rao, K.S., and Rohini, V.K. (1999). Agrobacterium-mediated

transformation of sunflower (Helianthus annuus L.): a simple protocol. Ann Bot. 83, 347-354.

Razzaq, A., Hafiz, I. A., Mahmood, I. and Hussain, A. (2011). Development of in planta transformation protocol for wheat, African Journal of Biotechnology, 10(5): 740-750.

Saharan, V., Yadav, R. C., Yadav, N. R., Ram, K. (2004). Studies on improved Agrobacterium-mediated transformation in two indica rice (Orya sativa L.). Afr J Biotechnol. 3(11): 572-575.

Saxena, K. B. (2008). Genetic improvement of pigeon pea- a review. Trop Plant Biol. 1, 159-178.

Shanower, T.G., Romeis, J. and Minja, E. M. (1999). Insect pests of pigeon pea and their management, Annu Rev Entomol. 44, 77-96.

Supartana, P., Shimizu, T., Nogawa, M., Shioiri, H., Nakajima, T., Haramoto, N., Nozue, M., Kojima, M. (2006). Development of simple and efficient in planta transformation method for wheat (Triticum aestivum L.) using Agrobacterium tumefaciens. J Biosci Bioeng, 102(3): 162-170.

Supartana, P., Shimizu, T., Shioiri, H., Nogawa, M., Nozue, M., Kojima, M., (2005). Development of simple and efficient in planta transformation method for rice (Oryza sativa L.) using Agrobacterium tumefaciens. J Biosci Bioeng, 100(4): 391-397.

Varshney, R.K., Chen, W. and Li, Y., (2011). 
Draft genome sequence of pigeon pea (Cajanus cajan), an orphan legume crop of poor farms. Nat Biotechnol. $10,1038$.

Wagiran A., Ismail I, Radziah C, Zain CM, Abdullah R (2010). Agrobacterium tumefaciens - mediated transformation in isopentyltransferase gene in japonica rice suspension culture. Aus $\mathbf{J}$ Crop Sci. 4(6): 421-429.
Zhao, Z.Y., Gu, W., Cai, T., Tagliani, L. A., Hondred, D. A., Bond, D., Krell, S., Rudent, M. L., Bruce, W. B., Pierce, D. A. (1998). Molecular analysis of $\mathrm{T}_{0}$ plants transformed by Agrobacterium and comparison of Agrobacteriummediated transformation with bombardment transformation in maize. Maize Genet Coop Newsl. 72, $34-37$

\section{How to cite this article:}

Rouf Ahmad Parray, Rahul Kaldate and Rahul Chavan. 2019. Optimization of In-planta Method of Genetic Transformation in Pigeon Pea (Cajanus cajan L. Millsp.). Int.J.Curr.Microbiol.App.Sci. 8(06): 50-62. doi: https://doi.org/10.20546/ijcmas.2019.806.008 